\title{
A Note on Terminology
}

\section{Why Holocaust "Revisionists" Are Really Deniers}

For a long time we referred to the deniers by their own term of "revisionists" because we did not wish to engage them in a name-calling contest (in angry rebuttal they have called Holocaust historians "exterminationists," "Holohoaxers," "Holocaust lobbyists," and assorted other names). ${ }^{1}$ We are well aware of David Irving's libel suit against Deborah Lipstadt, which involves, among other things, her calling him a Holocaust denier. We have given this matter considerable thought-and even considered other terms, such as "minimalizers"-but decided that "deniers" is the most accurate and descriptive term for several reasons:

I. When historians talk about the "Holocaust," what they mean on the most general level is that about six million Jews were killed in an intentional and systematic fashion by the Nazis using a number of different means, including gas chambers. According to this widely accepted definition of the Holocaust, so-called Holocaust revisionists are in effect denying the Holocaust, since they deny its three key components-the killing of six million, gas chambers, and intentionality. In an ad placed in college newspapers by Bradley Smith, one of the "revisionists" discussed in this book, he even uses this verb: "Revisionists deny that the German State had a policy to exterminate the Jewish people (or anyone else) by putting them to death in gas chambers or by killing them through abuse or neglect." 2

2. Historians are the ones who should be described as revisionists. To receive a Ph.D. and become a professional historian, one must write an original work with research based on primary documents 
and new sources, reexamining or reinterpreting some historical event-in other words, revising knowledge about that event only. This is not to say, however, that revision is done for revision's sake; it is done when new evidence or new interpretations call for a revision.

3. Historians have revised and continue to revise what we know about the Holocaust. But their revision entails refinement of detailed knowledge about events, rarely complete denial of the events themselves, and certainly not denial of the cumulation of events known as the Holocaust.

Holocaust deniers claim that there is a force field of dogma around the Holocaust-set up and run by the Jews themselves-shielding it from any change. Nothing could be further from the truth. Whether or not the public is aware of the academic debates that take place in any field of study, Holocaust scholars discuss and argue over any number of points as research continues. Deniers do know this. For example, they often cite the fact that Franciszek Piper, the head of the Department of Holocaust Studies at the Auschwitz-Birkenau State Museum, has refined the number killed at Auschwitz from four million to a little more than one million, arguing that this proves their case. ${ }^{3}$ But they fail to note that at the same time the numbers have been revised up-for example, the number of Jews murdered by the Einsatzgruppen during and after the invasion of the Soviet Union. ${ }^{4}$ The net result of the number of Jews killedapproximately six million-has not changed. In the case of Auschwitz and the other camps liberated by the Russians, since the end of the Second World War the Communists' efforts to portray the Nazis in the worst light possible led them to exaggerate the number of the Nazis' victims and the number of extermination camps. ${ }^{5}$ Scholars have had to clear through Communist propaganda to get to the truth about what happened. This sifting of data has resulted and will continue to result in Holocaust revision.

Thus, in this book, "Holocaust denial" is a descriptive term that allows for clear and accurate communication about who is being discussed. We adopt as our approach the sage advice of the seventeenth-century philosopher Baruch Spinoza: "I have made a ceaseless effort not to ridicule, not to bewail, not to scorn human actions, but to understand them." 